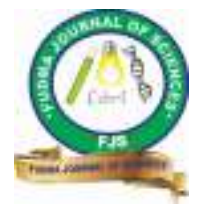

FUDMA Journal of Sciences (FJS)

ISSN online: $2616-1370$

ISSN print: 2645 - 2944

Vol. 4 No. 3, September, 2020, pp 252-255

DOI: https://doi.org/10.33003/fjs-2020-0403-272

\title{
PREVALENCE OF HAEMOPARASITES OF POLO HORSES AND THEIR EFFECT ON SOME HAEMATOLOGICAL PARAMETERS IN ZARIA NIGERIA
}

\author{
${ }^{1}$ U. M. Farouk ${ }^{2}$ G. A. Musa ${ }^{2}$ S. Ibrahim, ${ }^{2}$ M. S. Sabah \\ ${ }^{1}$ Veterinary Teaching Hospital Ahmadu Bello University, Zaria, Kaduna State. \\ ${ }^{2}$ Department of Veterinary Medicine Ahmadu Bello University, Zaria, Kaduna State. \\ Corresponding Author's email: ufum196868@gmail.com
}

\begin{abstract}
Haemoparasites are either intracellular or extracellular organisms that inhabit the blood stream of vertebrate hosts. This study was conducted in Zaria Nigeria inorder to investigate the prevalence of haemoparasites in polo horses and their effects on haematological parameters. Blood samples were collected from a total of 100 randomly selected horses from polo stables across Zaria. The blood samples were screened and examined using thin blood smear, buffy coat technique, and differential white blood cell count. From the results thirteen horses $100(13 \%)$ were found infected with haemoparasites. The prevalence of Theileria equi in local and exotic breeds was $5(9.4 \%)$ and4 $(8.5 \%)$ while for microfilaria it was $3(5.3 \%)$ and $1(2.1 \%)$. There were no Babesia or Trypanosomes found in the samples $0 \%$. Among sexes the prevalence of Theileria equi and microfilaria in males was $1(7.7 \%)$ while in females it was $(9.3 \%)$ and $3(3.4 \%)$. A high prevalence of Theileria equi and microfilaria was seen among old horses $6(9.3 \%)$ and $4(3.4 \%)$ compared to young $3(7.7 \%)$ and1 (7.7\%).There was no significant association between the presence of the infection and its effect on haematological values $(\mathrm{p}>0.05)$. In conclusion some haemoparasites were found in polo horses in Zaria. It is hereby recommended that routine vector control and prophylactic treatment should be carried out in stables.
\end{abstract}

Keywords: Polo horses, haemoparasites, prevalence, haematology.

\section{INTRODUCTION}

The health of animals can be threatened by the presence of parasites residing either inside or outside the host (Ademola et al., 2004). Haemoparasites are either intracellular or extracellular organisms that inhabit the blood stream of vertebrate hosts, such as (Babesia spp and Theileria spp),(Trypanosoma spp), or filarial worm (microfilaria) and are generally been shown to cause destruction of red blood cells resulting in anaemia, icterus, anorexia, weight loss and infertility. The effects of parasitic infection are more evident in young and undernourished horses. Disease factors have been reported to be limiting factors to improved livestock production in tropical Africa and are common causes of alterations in haematological values (Adamu et al., 2007).Indigenous horses have been used by institutional and private owners in Nigeria for pleasure riding, polo games, ceremonies, crowd control, entertainment and research (Ehizibolo et al.,2011). These uses have encouraged horse owners to import exotic breeds to overcome the limitations of the available local breeds (Saror, 1976). Horses are associated with royalty and some special traditional festivals in the northern parts of Nigeria (Bukar et al., 2007). There is increase interest in polo racing, durbar ceremonies and other horse sports in and around Zaria. Efforts made to determine the prevalence and other information is not commensurate to the increasing number of polo horses in Zaria. Hence the need to find out the prevalence of haemoparasites in polo horses and suggests ways for control and prevention.

\section{MATERIALS AND METHODS \\ Study Area}

The Zaria polo site is centrally located within Zaria with few stables within its premises. The other polo stables are situated in different parts of the city. Zaria is located within the Northern Guinea Savannah between latitude $11^{\circ} \mathrm{N}$ and $12^{\circ} \mathrm{N}$ and longitude $7^{\circ} \mathrm{E}$ and $8^{\circ} \mathrm{E}$, at an elevation of 650 meters above sea level. Zaria has two seasons; dry season (November to April) and rainy season (May to October). The average annual maximum and minimum temperatures are $33.17 \pm 0.67^{\circ} \mathrm{C}$ and $18.74 \pm 0.63^{\circ} \mathrm{C}$ respectively. The average monthly rainfall is $176.55 \pm 31.79 \mathrm{~mm}$, while the mean monthly relatively humidity is $46.39 \pm 5.67 \%$ (Meteorological Division, Department of Soil Science, A.B.U Zaria, 1992). 
Fig 1: Map of Nigeria, Kaduna State and Zaria polo site

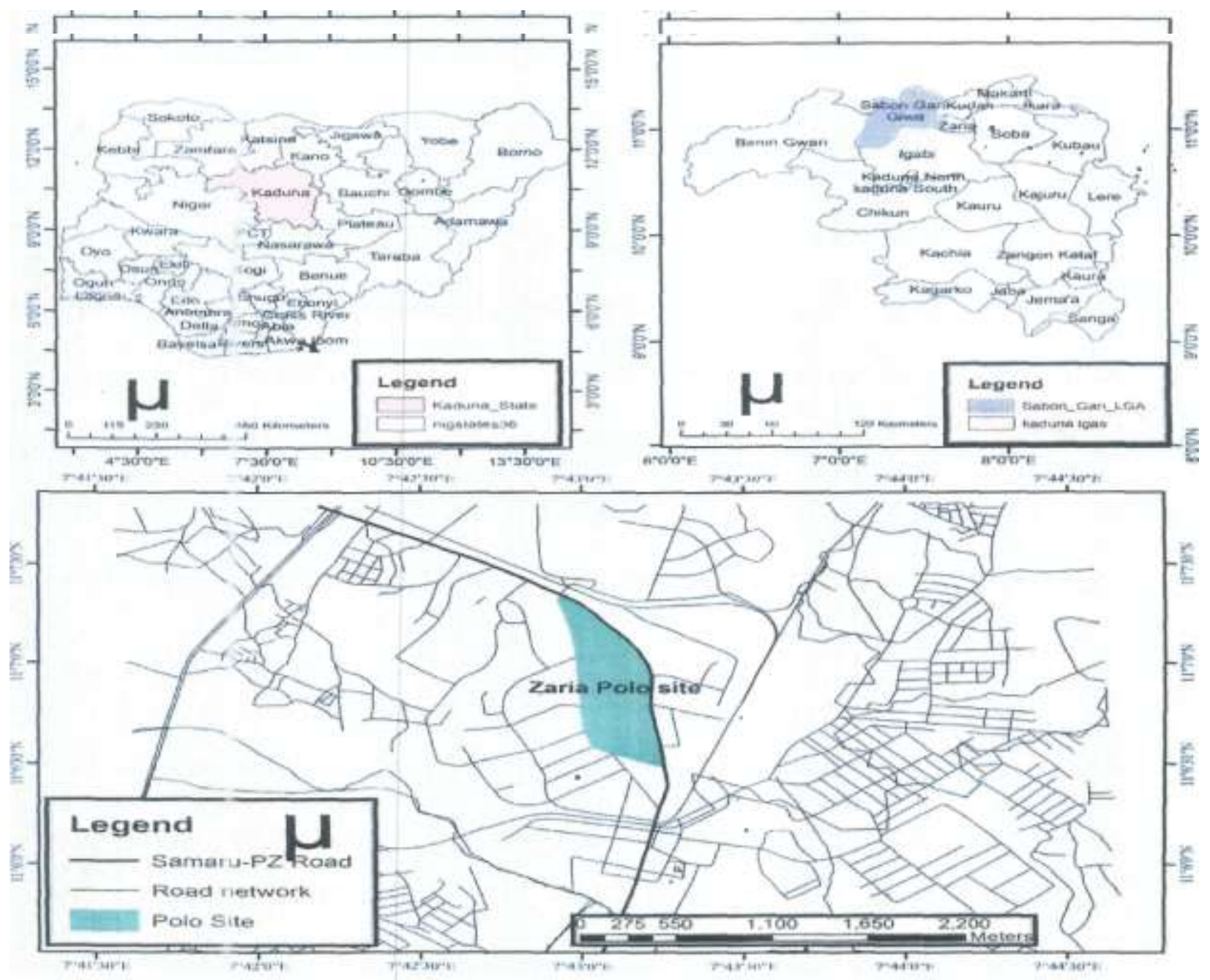

\section{Study Design}

The study was cross-sectional study and using simple random sampling technique, horses were sampled with reference to breed age and sex. The horses were divided into two categories according to their breeds as local or exotic, they were also grouped into young (4-7 years) and old (8-11years). One hundred (100) horses were sampled from the various polo stables in Zaria based on consent and availability.

\section{Sample Collection and laboratory analysis}

Under proper head restraint by halter, $5 \mathrm{ml}$ of blood samples was collected from individual horses from jugular vein, using a 21 gauge needle fixed to a $10 \mathrm{ml}$ syringe. The blood was immediately transferred into a properly labelled EDTA (Ethylene diamine-tetra acetic acid) sample bottles. These samples were placed on ice pack and transported immediately to the clinical pathology parasitology, and entomology laboratories of Ahmadu Bello University, Zaria for processing and analyses.

Blood samples collected where examined using; thin blood smear stained with Giemsa for identification of Theileria equi or Babesia caballi, microfilaria and Trypanosomes according to Gelfard (1995). Buffy coat was determined as described by Levine (1986). Packed Cell Volume (PCV) was determined using the procedure of Bull (2001). Erythrocyte count (RBC),differential white blood cell count and haemoglobin concentration $(\mathrm{Hb})$ was determined as described by Coles (1986). The Total protein (TP)was determined as described Babul et al.,(1969).

\section{Statistical Analysis}

Student t-test was used to analyse data obtained based on breeds, sex, age and haematology where $\mathrm{P}$ values equal to or less than 0.5 was regarded as significant. 


\section{RESULTS}

Distribution of haemoparasites based on breeds showed higher prevalence of Theileria equi 5(9.5\%), and microfilaria 3(5.3\%) among local breeds. The number of horses infected with Theileria equi and microfilaria based on sex was higher among the females $8(9.3 \%)$ and $3(3.4 \%)$. The Prevalence of Theileria equi and microfilaria based on age was higher among old horses $6(9.3 \%)$ and $4(3.4 \%)$ (Table 1$)$.

Table 1: Prevalence of haemoparasites of polo horses based on breed sex and age in the study area

\begin{tabular}{cccc}
\hline Variable & Number sampled & T. equi & microfilaria \\
\hline Breed & & & \\
Local & 53 & $5(9.5 \%)$ & $3(5.3 \%)$ \\
Exotic & 47 & $4(8.5 \%)$ & $1(2.1 \%)$ \\
Sex & & & \\
Male & 13 & $1(7.7 \%)$ & $1(7.7 \%)$ \\
Female & 87 & $8(9.3 \%)$ & $3(3.4 \%)$ \\
Age & & & \\
Young & 22 & $3(7.7 \%)$ & $0(0 \%)$ \\
Old & 78 & $6(9.3 \%)$ & $4(3.4 \%)$ \\
\hline
\end{tabular}

There was no decrease in Packed Cell Volume (PCV), Total Protein (TP), red blood cell (RBC), lymphocytes, eosinophils and band cells in the infected horses, however there was decrease in haemoglobin concentration (HC), white blood cell (WBC), neutrophils and monocytes (Table 2).

Table 2: Effect of parasites on Mean \pm SEM of haematological parameters

\begin{tabular}{lccc}
\hline Haematological parameters & Infected & Non-infected & p-value \\
\hline Packed Cell Volume (\%) & $38.50 \pm 2.16$ & $39.87 \pm 0.85$ & 0.698 \\
Haemoglobin concentration (g/dl) & $16.0 \pm 0.00$ & $12.36 \pm 0.42$ & 0.000 \\
Total Protein (g/L) & $8.50 \pm 0.17$ & $8.60 \pm 0.26$ & 0.749 \\
White Blood Cell $\left(\mathrm{x} 10^{3}\right)$ & $7.30 \pm 0.24$ & $8.37 \pm 0.26$ & 0.004 \\
Red Blood Cell (1x10 $\mu$ l) & $6.90 \pm 0.37$ & $6.70 \pm 0.14$ & 0.619 \\
Neutrophils (\%) & $3.78 \pm 0.16$ & $5.10 \pm 0.19$ & 0.018 \\
Lymphocytes (\%) & $3.33 \pm 0.14$ & $3.05 \pm 0.13$ & 0.162 \\
Monocytes (\%) & $0.20 \pm 0.66$ & $0.61 \pm 0.01$ & 0.000 \\
Eosinophil (\%) & $0.00 \pm 0.00$ & $0.68 \pm 0.01$ & 0.092 \\
Basophils (\%) & $0.00 \pm 0.00$ & $0.00 \pm 0.00$ & 0.000 \\
Band cells (\%) & $0.00 \pm 0.00$ & $0.03 \pm 0.01$ & 0.140 \\
\hline
\end{tabular}

The decrease in white blood cell count in the infected horses could be attributed to stress produced by haemoparasites

\section{DISCUSSION}

The study indicated presence of haemoparasites in polo horses in Zaria. The prevalence was higher than the reported $9 \%$ by Biu et al., (2016) and 3.4\% by David et al., (2012) in some polo and racing horses in private stables in some states in northern Nigeria using the same screening techniques. Undernourished horses, seasonal variation and endemicity of the vectors that transmit the parasites in the different study areas (Schein 1988) could be some of the factors among others that may influence the difference in prevalence.

The high prevalence observed in the local breeds compared to the exotic could be due to management practice, since exotic breeds are well housed in insect proof stables. These findings concur with what was reported by David et al., (2012). The study also revealed high prevalence in females relative to the males. These could be attributed to the ratio of males and females sampled in all the stables. Generally polo players keep more females with few males and geldings in their stables. Similar findings were observed by Piyush et al., (2016).

The prevalence was observed to be high in old horses compared to young. Age has been shown to affect resistance to diseases Losos (1986).In this study the numbers of old horses sampled were more than the young and that may have influenced the prevalence. leading to the release of cortisol (Fleming 1997) which subsequently results in decrease in all the cellular elements or a single cellular component such as lymphopenia, neutropenia, and monocytopenia (Esievo and Saror, 1983).

In conclusion this study has established the presence of haemoparasites in the sampled polo horses with no significant decrease on haematological values. It is hereby recommended that vector control as well as prophylactic treatment should be carried out in stables. Further investigation using superior sensitive tests like Polymerase Chain Reaction (PCR) and Enzyme linked immunosorbent assay (ELISA) are also recommended.

\section{REFERENCES}

Adamu, S., Adebayo, I.T., Useh, N.M., Bisalla, M., Sambo, S. J. and Esievo K.A.N. (2007).Chemical analysis of urinary constituents in Cattle presented for slaughter at Zaria abattoir: Veterinary Research, 1: $(57-60)$.

Ademola I.O., Fagbemi B.O., Idowu S.O. (2004). Evaluation of the anthelmintic activity of Khaya senegalensis extract against gastrointestinal nematodes of sheep: in-vtro and in-vivo studies. Veterinary Parasitology 122: (151-164) 
Babul, J and Stellwajen (1969). Measurement of protein concentration with interferences optics. Anal Biochemistry 4; (216-21)

Biu, A.A. Ahmed, M.I. and Yunus, AI (2006).Prevalence of Equine Babesiosis in Maiduguri Nigeria. International Journal of Biomedical and Health Sciences 2. (2)

Bukar, M.M. Sadiq M.A. and Geidam, Y.A. (2007). A survey of cutaneous neoplasms among horses used for cultural festivals in Borno State, Nigeria. Nigerian Veterinary Journal 2: (27-33)

Bull (2001). Recommendations for reference method for the packed cell volume (ICSH Standard) Laboratory Haematology 7 (3) (148-170)

Coles, E.H. (1986). Veterinary Clinical Pathology, 4thed. pp. 374-400. W.B.Saunders, Comp.

David, O. E, Joshua, I, Peter, O. Kinsley, E O, Goni, I. and Josiah O. S (2012).Prevalence and Significance of Parasites of Horses in Some States of Northern Nigeria. Journal of Equine Science 23: $(1-4)$

Ehizibolo, D.O., Gusi, A.M., Ehizibolo, P.O., Mbuk, E.U., and Ocholi, R.A. (2011). Brucellosis in horse stables in two northern states of Nigeria. Journal of Equine Science. 22: (1719)

Esievo, K. A. N. and Saror, D. I. (1983). Leukocytes Response in in Experimental Trypanosoma vivax Infection in Cattle. Journal of Comparative Pathology, 93: (165-169).
Fleming, M.W. (1997). Cortisol as an indicator of severity of parasitic infections of Haemonchus contortus in lambs (Ovis aries).Comparative Biochemistry and Physiology Part B:Biochemistry and Molecular Biology vol 116 pp 41-44

Gelfard, J.A. (1995). Babesiosis. In: Mandell, E.L.; Bennett, J.E.; Dolin, R. (Eds.). Principles and practice of infectious diseases. $4^{\text {th }}$ ed. Churchill Livingstone, New York, 58: 1-8.

Levine, R.A. Hart, A.H. and Wardlaw, S.C. (1986). Quantitative Buffy Coat Analysis of Blood Collected From Dogs, Cats, and Horse. Journal of the American Veterinary Medical Association 189(6) (670-3)

Losos, G.J. (1986). Infectious tropical diseases of domestic animals. Longman Scientific and Technical Group, pp. 3-9.

Piyush G. D. Patel, J.S Vijay L.P, Prasad, K..K. Murabiya, D.V.and P.B. Patel P.M. (2016).Prevalence of equine piroplasmosis in and around saurshtra region in horses. International Journal of Science, Environment and technology 5: (3)

Saror, D.I. (1976). Haematological values in Nigerian partArab Stallions. Veterinary Records 99: (397-398).

Schein, E. (1988). Equine babesiosis In: Ristic, M. (ed.). Babesiosis of domestic animals and man. CRC Press, Florida, pp. $198-208$ 